\title{
Childhood involvement of herpes zoster
}

\section{Çocukluk çağı herpes zoster tutulumları}

\author{
Sema ERDOĞMUŞ ${ }^{1}$, Gökçen CERRAH ${ }^{1}$, Asuman KIRAL², Zuhal Aydan SAĞLAM ${ }^{1}$
}

\section{ABSTRACT}

Herpes Zoster ( $\mathrm{HZ})$ is a subgroup of herpesviredea sp. consisting of a double-strand DNA virus. It is a worldwide common clinical problem and has an important mortality and morbidity rate among immunsuppresed patients. $\mathrm{HZ}$ infections are often seen in adults, however its incidence is $0.45 / 1.000$ in $0-14$ years-old children. Here, we present two children with different clinical presentations. Our aim is to emphasize important complications of $\mathrm{HZ}$ infections and prevent them with early diagnosis and appropriate treatment.

Key words: herpes zoster, conjunctivitis, dermatitis, complications

\section{Giriş}

Herpes zoster (HZ) çift sarmallı DNA'dan oluşan Herpes virüs alt grubudur ${ }^{1}$. Varicella zoster virüsünün (VZV) arka kök ganglionlarına sessizce yerleşmesi ve periodik olarak reaktive olmasıyla rekürren infeksiyon oluşturur ${ }^{1-3}$. Tüm dünyada yaygın bir klinik sorun olan HZ infeksiyonları özellikle immun supresiflerde önemli mortalite ve morbiditeye yol açmaktadır ${ }^{1,4}$. Hücresel immün yetmezlik, malignite, immün supresif ilaçlar, subklinik suçiçeği geçirmek, profilaktik asiklovir kullanmak, varicella aşısı HZ gelişimini kolaylaştıran faktörlerdir ${ }^{1,4}$. Virüs, spesifik antijeninin farklılığına göre HSV-1 ve HSV-2 olmak üzere ikiye ayrılır ${ }^{5}$. Genital infeksiyonlarda, lomber ve sakral dermatozomal tutulumlardan HSV-2 sorumluyken, oral infeksiyonlardan ve göz tutulumundan HSV-1 sorumludur. Latent infeksiyon yapabilme kapasitesine sahip olan HSV-1, HZ'in korneal tutulumlarından sorumludur. Trigeminal ganglionlarda latent kalan virüs kor-

\section{öz}

Herpes Zoster (HZ) tüm dünyada yaygın bir klinik sorun olup, özellikle immunsupresiflerde ciddi morbidite ve mortaliteye yol açmaktadır. HZ infeksiyonları sıklıkla erişkinlerde görülmekle beraber, 0-14 yaş arası çocuklarda insidansı 0.45/1000'dir. Makalenizde, erken yaşta görülen farklı dermatom tutulumları olan 2 çocuk olgu ele alınmıştır. Bu olgular sayesinde özellikle birinci basamakta erken teşhis ve doğru tedavi ile komplikasyonların önlenmesi amaçlanmıştır.

Anahtar kelimeler: herpes zoster, konjunktivit, dermatit, komplikasyon

neal epitelyal hücreleri hedef alır. Epitelyal hücreler proinflamatuar sitokinler INF- $\beta$, IL-6, TNF- $\alpha$, IL-8 artIşına neden olur. Bu mediyatörlerin artışı, nötrofil ve mononükleer lenfositleri artırarak antiviral aktiviteyi başlatır. Eğer bu aktivite kontrol altına alınamazsa korneal neovaskülarizasyona ve daha sonra artan inflamasyon korneal transplantasyona kadar ilerleyebilen görme kaybına yol açmaktadır ${ }^{6}$.

\section{OLGU 1}

Altı yaşındaki erkek hasta 2013 Nisan ayında Göztepe Eğitim ve Araştırma Hastanesi Çocuk Polikliniğine göz çevresinde ödem ve yara yakınmaları ile getirildi. Hastanın öyküsünde 5 gün önce ateş ve boğaz ağrısı nedeniyle ASM'ye başvurdu. Hastaya üst solunum yolu infeksiyonu tanısıyla oral ibuprofen ve sefdinir tedavisi başlandığı öğrenildi. Hasta tedavisinin 5. gününde mevcut yakınmalarına göz çevresinde ödem ve yara oluşumunun da eklenmesiyle kliniğimize gel-

Received: 05.08.2015

Accepted: 28.08.2015

${ }^{1}$ İstanbul Medeniyet Üniversitesi, Göztepe Eğitim ve Araştırma Hastanesi, Aile Hekimliği Kliniği

${ }^{2}$ Istanbul Medeniyet Üniversitesi, Göztepe Eğitim ve Araştırma Hastanesi, Çocuk Sağlığı ve Hastalıkları

Yazışma adresi: Dr. Sema Erdoğmuş, İstanbul Medeniyet Üniversitesi, Göztepe Eğitim ve Araştırma Hastanesi, Aile Hekimliği Kliniği, Göztepe-İstanbul

e-mail: sem_erdgms@hotmail.com 
di. Geliş muayenesinde genel durumu iyi, şuuru açık, ateşi $37,5^{\circ} \mathrm{C}$ derece, solunum sayısı 18/dk., TA: 100/70 $\mathrm{mm} / \mathrm{Hg}$, nabız 112/dk., boy kilo persantilleri 50p-75 $\mathrm{p}$ aralığında saptandı. Baş boyun muayenesinde sağ göz çevresinde krutlu lezyonlar, ödem, konjuktivada hiperemi ve pürülan akıntı mevcuttu. Lenfadenopati saptanmayan hastada orofarenks hiperemikti ve oral mukozada yaygın aftlar mevcuttu. Diğer sistem muayeneleri ise doğaldı. Geliş laboratuvar değerleri: WBC: $4.600 \mathrm{~mm}^{3}, \mathrm{Hb}: 11,5 \mathrm{~g} / \mathrm{dl}, \mathrm{Hct}: \% 33, \mathrm{MCV}: 77.1$ um $^{3}$, trombosit: $286000 / \mathrm{mm}^{3}$, CRP: $0.33 \mathrm{mg} / \mathrm{dl}$, sedimantasyon $20 \mathrm{~mm} / \mathrm{saat}$, glukoz: $91 \mathrm{mg} / \mathrm{dl}$, üre:23 $\mathrm{mg} / \mathrm{dl}$, kreatinin: $0.33 \mathrm{mg} / \mathrm{dl}$, AST:30 mg/dl, ALT:20 $\mathrm{mg} / \mathrm{dl}$ olup, normal sınırlarda saptandı. Hastadaki ödem nedeniyle preseptal selülit düşünülerek maxillofasiyal BT ve fasiyal orbital MR istendi. Yapılan görüntülemelerde patolojik bir bulgu saptanmadı. Ateş, göz çevresindeki krutlu lezyonlar, konjuktivada hiperemi ve oral mukozada aftların olması nedeniyle $\mathrm{HZ}$ $H Z$ düşünüldü (Figür 1) ve göz konsultasyonu istendi. Göz konsultasyonu sonucunda lezyonların yineleyen dermatozomal tutulumlar nedeniyle herpetik zoster konjuktiviti olduğuna karar verildi. Bu doğrultuda tedaviye sekonder bakteriyel infeksiyon açısından oral $40 \mathrm{mg} / \mathrm{kg} /$ gün olarak sefdinirle devam edilmesi, sistemik asiklovire ek olarak cilt lezyonları için topikal asiklovir, fusidik asit jel, konjuktivit için topikal moksifloksasin kullanılması önerildi. Hastanın kontrollerinde lezyonlarının gerilediği saptandı.

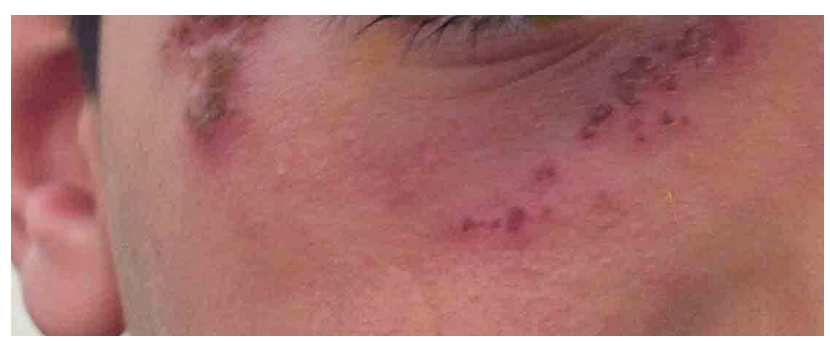

Figür 1. Herpes konjuktiviti ve periorbital trigeminal Herpes dermatiti.

\section{OLGU 2}

On yaşında erkek hasta 2013 Nisan ayında Göztepe Eğitim ve Araştırma Hastanesi Acil Polikliniğine kusma, ishal ve kalça ağrısı yakınmasıyla başvurdu. Anamnezinde 4 gündür devam eden ishali olduğu o gün kus- manın başladığı, 3 gündür kalçasında ağrı ve yanma olduğu belirtilen hasta herhangi bir sağlık kuruluşuna başvurmamış ve tedavi almamaktaydı. Hastanın özgeçmişinde 3 yaşında su çiçeği geçirdiği öğrenildi. Fizik muayenesinde genel durum iyi, şuur açık, ateş $37.2^{\circ} \mathrm{C}$, solunum sayısı 12, TA:105/70 mm/Hg, nabız: 102 ritmik, boy-kilo persantilleri 50p-50p saptandı. Başvuru laboratuvar değerleri WBC: $5.000 \mathrm{~mm}^{3}, \mathrm{Hb}: 12.6 \mathrm{~g} /$ dl, Hct: \%38.6, MCV: 78.9 um $^{3}$, trombosit:127.000/ $\mathrm{mm}^{3}, \mathrm{CRP}: 0.33 \mathrm{mg} / \mathrm{dl}$, Sedimantasyon: $10 \mathrm{~mm} / \mathrm{saat}$, glukoz :93 mg/dl, üre: $25 \mathrm{mg} / \mathrm{dl}$, kreatinin: $0.53 \mathrm{mg} /$ dl, AST:19 mg/dl, ALT:11 mg/dl şeklindeydi. Kalçasında tek bir dermatom boyunca yerleşmiş makülopapüler eritem alanları ve veziküler ağrılı lezyonlar olması nedeniyle zona tanısı konuldu (Figür 2). Hastaya oral asiklovir ve destek tedavisi olarak antihistaminik, Islak pansuman, analjezik başlandı ve 3 gün sonra kontrole çağırıldı. Tedavinin 3. gününde veziküler lezyonların krutlanmaya başladığı görüldü.

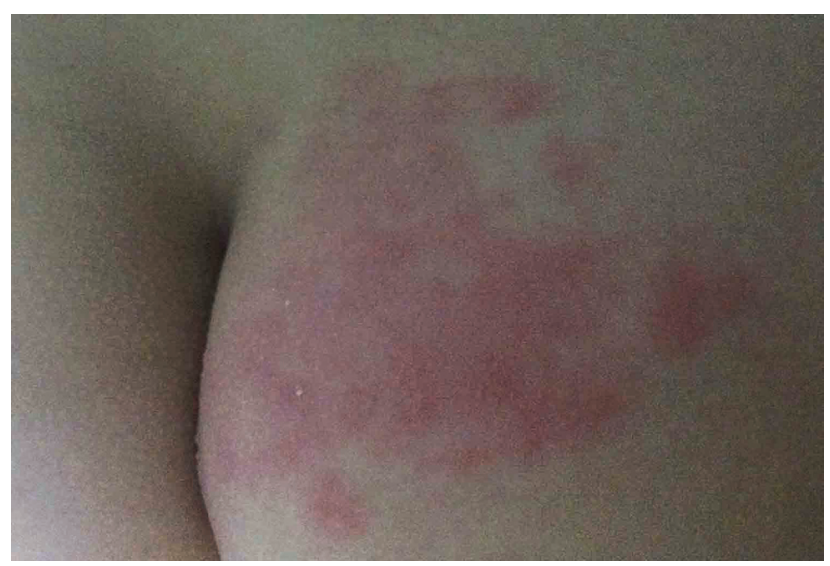

Figür 2. Sakral Herpes dermatiti.

\section{TARTIŞMA}

Herpes zoster infeksiyonu sıklıkla erişkinlerde görülmekle birlikte, 0-14 yaş arası çocuklarda insidansı 0.45/1000 yıl oranındadır. National Health and Nutrition Examination Survey (NHNS) tarafından Amerika'da 1999-2004 yılları arasında yapılan araştırmada, 14-19 yaş arası adolesanlarda HSV-1 prevalansı \%39 olarak bulunmuştur ${ }^{2}$. Çocukluk dönemi zona zoster infeksiyonu altta yatan immünsüpresyon durumlarında daha sık görülmektedir. Diğer taraftan immünsupreesyonu olmayan kişilerde de daha ender 
de olsa görülebilir ${ }^{1}$. Çocukluk çağında $\mathrm{HZ}$ geçiren olguların büyük çoğunluğu 5 yaşından büyük çocuklar oluştururken, olgularımız 6 ve 10 yaşlarında olması $\mathrm{HZ}$ nin en tipik görülme yaş aralığı ile uyumluydu ${ }^{1,3}$. Klinikte hastalarda $\mathrm{HZ}$ en sık torakal (\%75) ve lomber dermatom (\%11) bölgelerinde izlenmekte iken, düşük oranda ise trigeminal sinir ve sakral dermatom tutulumları görülebilir. Ayrıca kranial sinirlerin tutulumu sonucu konjuktivit, anterior üveit ve Ramsey-Hunt sendromu ender olarak görülebilecek diğer komplikasyonlardandır ${ }^{1}$. Konjuktivit genellikle unilateral olup blefarit ve preaurikular lenfadenopati eşlik eder ve konjuktiva ödemli olmasına rağmen, ender olarak pürülan akıntı olur ${ }^{3}$. Olgu 1'de HSV-1'in trigeminal sinir tutulumuna bağlı konjuktivit, olgu 2'de HSV-2'nin sakral dermatom tutulumuna bağlı zona görülmektedir. HSV'ye bağlı göz tutulumları blefarit, konjunktivit, epitelyal trofik ülser, nekrotizan stromal keratit, immun stromal keratit, anterior üveit, endotelit ve iridosiklit şeklinde olabilir ${ }^{5,7,8}$. Genç çocuklarda nonepidemik foliküler konjunktivit yaptığıda bilinmektedir $^{9}$. Göz tutulumunun patofizyolojisinde olası 2 ayrı mekanizmadan söz edilmektedir. Öncelikle döküntülerin olduğu primer viremi döneminde kan yoluyla, ikincisine göre ise döküntüler geçtikten sonra immun reaksiyona bağlı otoimmun ve alerjik reaksiyonların rol aldığı patolojik süreçte göz tutulumu olmaktadır ${ }^{7}$. Olgu 1 bize döküntülerin olduğu primer viremi döneminde gelmişken, olgu 2 ise döküntüler geçtikten sonra immun sistemini baskılayan akut gastroenterit nedeniyle gelişen $\mathrm{HZ}$ infeksiyonu ile başvurmuştur. $\mathrm{HZ}$ infeksiyonunun tanısı sıklıkla klinik olarak konur. Net olmayan klinik öykü ve stromal skarlarla gelen hastalara tanı konması oldukça güçtür. Bu yüzden gelişmiş ülkelerde korneal körlüğün en sık nedenidir ${ }^{10,11}$. $H Z$, çocukluk döneminde klinik olarak erişkinlerden farklılık gösteri, genel olarak hastalık süresi çocuklarda daha kısa olup, komplikasyonları daha enderdir ${ }^{12}$. Olgu 1'deki hasta konjunktival hiperemi ve frontal dermatozomal tutulum evresinde tanı alıp parenteral asiklovir+destek tedavisi başlandığı için keratit gelişimi önlendi. Herpetik göz tedavisinde tam bir görüş birliği olmasa da topikal steroid ve sistemik asiklovir tedavisi genel kabul görmektedir ${ }^{8}$. Ancak olgumuzda sistemik asiklovir tedavisi sonrasında hastamızda gö- rülen 2-3 gün içindeki hızlı iyileşme seyri nedeniyle steroid tedavisine gerek görülmemiştir. Olgu 2'deki hastada ise sakral dermatozomal tutuluma bağlı veziküler lezyonların varlığıyla $\mathrm{HZ}$ tanısı konulup oral asiklovir ve destek tedavisi başlanmıştır.

Sonuç olarak, HZ çocukluk dönemde oldukça ender görülmekle beraber, yetişkinlerden klinik olarak farkIıdır. HZ infeksiyonu nedenli komplikasyonlar çocukluk döneminde genellikle görülmez. Buna rağmen, asiklovir tedavisinin erken başlanması iyileşme sürecini hızlandırıp olası ender de görülse komplikasyonları azaltmaktadır. Bu yazıda ender görülmesi nedeniyle herpes zosterli iki çocuk olgusu üzerinden $\mathrm{HZ}$ enfeksiyonuna ait klinik özelliklerinin yanında tedavi yaklaşımına değinilmek istenmiştir.

(Her iki olgunun yayınlanmasında hasta ve yakınlarının izni alınmıştır.)

\section{KAYNAKLAR}

1. Yalaki Z, Ozturk A, Tasar MA, et al. Sağlıklı Çocuklarda Herpes Zoster Enfeksiyonu. Çocuk Enf Derg 2010; 4: 96-9. http://dx.doi.org/10.5152/ced.2010.13

2. Richard EB, Robert MK, Hal BJ. Herpes Simplex Virus. Nelson

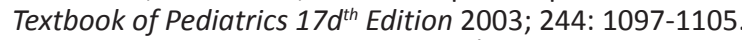

3. Sen S, Bayram N, Sahbudak ZB, et al. İki Çocuk Enfeksiyon Kliniğinin Herpes Zoster Deneyimi. Türk Ped Arş 2013; 48: 40-3.

4. Yagmur G, Ozbal Y, Gokahmetoglu S, et al. Herpes Simpleks Virus Enfeksiyonu Şüphesi Olan Hastaların Klinik Örneklerinde Üç Farklı Yöntemle HSV Varlığının Araştırılması. Mikrobiyol Bul 2010; 44: 47-56.

5. Cakmakcı S, Akova YA, Aydın P. Okuler Herpesde Ön Segment Bulguları Ve Tedavisi. Türkiye Klinikleri J Ophtalmol 2000; 9: 69-76.

6. Terasaka Y, Dai M, Yakura K, et al. Induction Of IL-6 In Transcriptional Networks In Corneal Epithelial Cells After Herpes Simplex Virus Type 1 Infection. IOVS 2010; 51-5.

7. Coban DT, Firidin G. Konjuktiva tutulumlu bir suçiçeği olgusu. Journal of Clinical and Analytical Medicine 2011; 2: 97-98.

8. Seker UE, Asık NS, Ture G. Herpetik Ön Üveitlerde Tedavi Sonuçlarımız. Ege Tıp Dergisi 2012; 51: 245-248.

9. Manav G, Akarcay K. Göz İnfeksiyonlarına Neden Olan Mikroorganizmalar. Aknem Derg 1991; 5: 396-400.

10. Robert PY, Anja L, Metzner S, et al. Spesific Antibody Production In Herpes Keratitis: Intraocular Inflammation And Corneal Neovascularisation As Predicting Factors. Graefe's Arch Clin Exp Ophthalmol 2006; 244: 210-215. http://dx.doi.org/10.1007/s00417-005-0014-7

11. Berna AB, Mehmet $B$, Sevil T, et al. Kliniğimize Yatırılarak Tedavi Edilen Keratit Olgularının Analizi. Uludağ Üniversitesi Tıp Fakültesi Dergisi 2011; 37: 155-157.

12. Sever E, Canan G, Evren S et al. İki Sağlıklık Çocukta Herpes Zonster. Yeni Tıp Dergisi 2010; 27: 51-52. 